\title{
Design of Type-1 Servo Systems Based on a Dual Observer and Its Application to Positioning Control of Flexible Structures
}

\author{
Takahiko Mori Member (Gifu Natinal College of Technology, mori@gifu-nct.ac.jp) \\ Katsuhiko Fuwa Non-member (Nagoya Institute of Technology, kandou@nitech.ac.jp) \\ Hisashi Kando Member (Nagoya Institute of Technology, fuwa@nitech.ac.jp) \\ Takashi Suzuki Student Member (Nagoya Institute of Technology, ta-suzuki@watt.elcom.nitech.ac.jp)
}

Keywords: dual observer, pre-filter, servo control design, internal model principle, flexible structure

\section{Introduction}

This paper presents a new design method of servo control system based on dual observers for the positioning of flexible structures with the elasticity. In order to reduce the sensors and to suppress spillover phenomena with caused by ignored elastic modes of the plant, we introduce an input pre-filter which possesses low pass characteristics First, On the basis of the augmented system which is expressed by the plant, an input pre-filter and an integrator based on Internal Model Principle, we design the servo compensater including dual observers for matching desired models. Second, some results of numerical simulations are given.

\section{Design of Servo Control System Based on Dual Observers}

The aim of our study is to design servo compensator for the flexible structures which satisfies the following design specifications :

S.1) Servo control

S.2) Stabilizing control of the closed loop system while suppessing elastic vibrations of the plant

In order to meet these requirements, we propose :

C.1) Control design involving integrator based on Internal Model Principle,

C.2) Expand the input space of the augment system by using dual observers.

Proposed servo control system based on dual observers is shown in Fig. 1

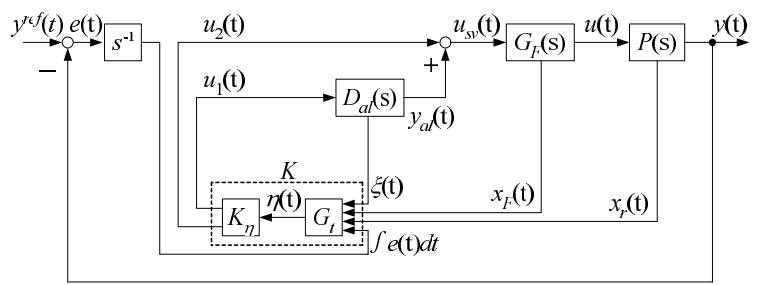

Fig. 1. Proposed servo control system

\section{Simulation}

In order to verify the validity of proposed servo compensator, we perform numerical simulations about two examples. In this summary we show a positioning control of a flexible arm as an example. The following servo problem is given.

Servo problem: We set the initial rotational angle of the motor $\theta(t)=0[\mathrm{rad}]$, and the reference value of the motor changes for $\theta(t)=0[\mathrm{rad}]$ to $0.1[\mathrm{rad}]$ at $1[\mathrm{sec}]$.

Fig. 2 shows simulation results. It forces the motor to follow the stepwise reference, while stabilizing the closed loop system and suppressing elastic vibrations of the arm to the satisfied level.

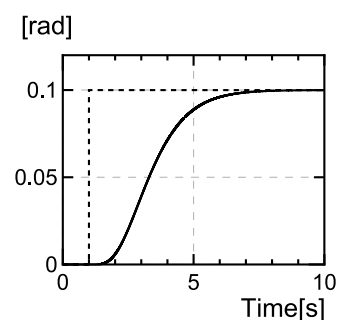

$\left[\times 10^{-7}\right]$ ] (a)

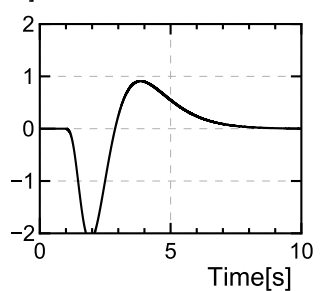

(c) 2nd mode

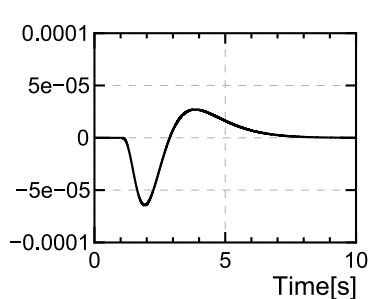

(b) 1 st mode

(d) 3rd mode

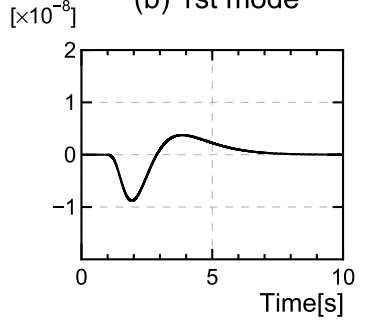

Fig. 2. Simulation results via proposed method

\section{Conclusions}

We presented a new design method of servo control system based on dual observers for the positioning of a flexible structures with the elasticity. From numerical simulations results, it was showed the satisfied results. 


\section{デュアルオブザーバを用いた積分型サーボ系設計法と 柔軟構造物への応用}

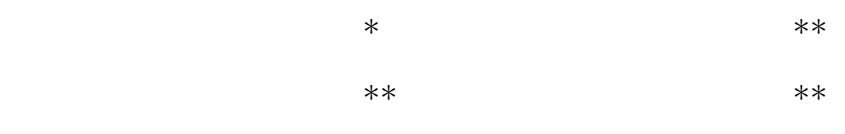

Design of Type-1 Servo Systems Based on a Dual Observer and Its Application to Positioning Control of Flexible Structures

Takahiko Mori*, Member, Katsuhiko Fuwa**, Non-member, Hisashi Kando**, Member, Takashi Suzuki**, Student Member

This paper presents a new design method of servo control system based on a dual observer for the positioning of flexible structures. In order to reduce the sensor costs and to suppress spillover phenomena which are caused by ignored elastic modes of the plant, we introduce an input pre-filter which possesses low pass characteristics. First, we consider a generalized plant, which is formulated as an augmented system which is expressed by the plant, the pre-filter and an integrator based on Internal Model Principle. Second, we expand the input spaces of the generalized plant by using the dual observer for matching to desired models. Third, we show our proposed design method which satisfies the design specifications. Finally, some results of numerical simulations are given in order to verify the usefulness of our method.

キーワード : デュアルオブザーバ, 前置フィルタ, サーボ系, 内部モデル原理, 柔軟構造物

Keywords: dual observer, pre-filter, servo system, internal model principle, flexible structure

\section{1.はじめに}

近年 , 宇宙構造物は作業範囲の拡大による長大化 , コス 卜の削減や動作の高速化による軽量化が進み, 弾性変形や 弾性振動を有する柔軟構造物としてよく扱われる。关のた め，振動抑制を考慮した制御方策を考える必要がある。こ れまでにセンサを用いた柔軟構造物の振動抑制に関する研 究が幾つか報告されているが(1)(2), 軽量化, 低コスト化, 設置場所の制限および維持管理の問題から，必ずしもセン サを使用できるとは限らない。

乥こで, 振動計測の為のセンサを低減する観点からアプ ローチした研究が求められている。このような研究では, 制御器の低次元化の目的から，分布定数モデルを有限次元 近似して，低次元の弾性モードまで考慮した設計モデルを 用いることが多い。このとき，無視された残留モードによ るスピルオーバ現象を回避する方法を考えなければならな

\footnotetext{
* 岐阜工業高等専門学校

干 501-0495 岐阜県本巣市上真桑 2236-2

Gifu Natinal College of Technology

2236-2, Kamimakuwa, Motosu, Gifu 501-0495

** 名古屋工業大学

干 466-8555 名古屋市昭和区御器所町

Nagoya Institute of Technology

Gokiso, Showa, Nagoya, Aichi 466-8555
}

い。これまでに , フレキシブルアームの $H_{\infty}$ 制御理論を用 いた振動抑制制御 ${ }^{(3)}$, フレキシブル倒立振子-台車系に対す る $H^{\infty}$ サーボ設計 ${ }^{(4)}$ の研究が行われている。文献 (3) で は, 重みによって $H_{\infty}$ 補償器に高域遮断特性を持たせてい る。しかし周波数領域に基づいた混合感度問題による保守 的な設計のため, 所望通りの高域遮断特性が実現できてい るか不明確であり, 過渡特性も考慮されていない。文献 (4) では, $H_{\infty}$ 補償器の非最小位相問題を解決する為に速度セ ンサを必要とし, 設計時の補償器の次数が高くなりすぎる 問題があった。

一方，著者の 1 人は，フレキシブル倒立振子-台車系を制 御対象に, 高域遮断特性を有する前置フィルタ ${ }^{(5)}$ を適用し た周波数依存型最適サーボ系を提案した ${ }^{(6)}$ 。歪センサ等の 力学量検出装置を用いず振動抑制を行っているが, スピル オーバ現象を回避するために入力側に配置した前置フィル 夕の遮断特性 (固有周波数と減衰係数) が状態フィードバッ クにより劣化する為，任意に指定できない問題がある。

乥こで, 本論文では, 上記問題を解決する為の新しいサー ボ系を提案する。提案するサーボ系はデュアルオブザーバ(7) との併合系を構成する構造となっている。デュアルオブザー バは, 制御対象と直結させることにより, 谷の直結系の入力 空間の次数を高める特徵を有し, システム外乱の抑制 ${ }^{(8)(9)}$ や零点配置 ${ }^{(10)}$ (11) など従来の状態フィードバック制御では 困難な問題に対処することができる補償器である。このよ 
うな特性を生かすと, 単なる極配置だけでなくシステム行 列の構造か指定できるので, 補償器と所望の前置フィルタ を分離して, 前置フィルタの高域遮断特性を劣化させずに 保存することが可能となる。光の結果，スピルオーバに伴 う振動の抑制を図れるものとなっている。

まず，設計仕樣を満足する制御系を設計する。次に，デュ アルオブザーバと制御対象からなる直結系の入力空間の次 数を制御対象の光れより高める。关れから，システム行列 の構造を指定した状態フィードバック則を定式化し，補償 器の設計を行う。さらに, 前置フィルタと状態間の非干渉 化を行った上で, 問題の解法を明確にする。最後に，応用 例として $2 つ の$ 柔軟構造物について, 従来の状態フィード バック制御による手法と比較して提案するサーボ法が有効 であることを数値シミュレーションにより検証する。1 例 目に, 構造が簡単な 1 リンク・フレキシブルアームム ${ }^{(12)}$ を, 2 例目に, 劣駆動系である 1 リンク・フレキシブル倒立振 子-台車系についても検証を行う。

\section{2. 制御系の構成}

本研究では, 柔軟構造物を制御対象に, 次の設計仕樣

S.1）目標值追従

S.2） · 内部安定化

・高域遮断特性を有する前置フィルタの実現

を満足するよう制御系を設計する。具体的には次の手法

C.1） 内部モデル原理に基づいた積分器の導入

C.2） デュアルオブザーバを用いた入力空間の拡大

を行うことにより，上記の仕樣を実現する。デュアルオブ ザーバは, 拡大した入力空間の自由度を用いて，任意の閉 ループ極を指定することができる。图 1 に提案するデュア ルオブザーバを併合した制御系を示す。

$P(s)$ は可制御な制御対象， $G_{F}(s)$ は前置フィルタ, $D_{a l}(s)$ はデュアルオブザーバ, $s^{-1}$ は積分器を示す。 $u(t) \in R$, $y(t) \in R$ は各々制御対象の入力及び出力 , $x_{r}(t) \in R^{n \times 1}$, $x_{F}(t) \in R^{2 \times 1}, e(t) \in R$ は各々制御対象の状態変数の推 定量, 前置フィルタの状態変数, 積分器の入力, $u_{1}(t) \in$ $R^{(N-1) \times 1}, \xi(t) \in R^{(N-1) \times 1}, y_{a l}(t) \in R$ は各々デュアル オブザーバの入力, 状態変数, 出力, $y^{r e f}(t) \in R$ は目標 值, $u_{s v}(t) \in R$ は 2.1 節で議論される拡大系の入力, $N$ は 同じく拡大系の次数, $u_{2}(t) \in R$ は新しい制御入力である。

〈2.1〉 入力空間の拡大制御対象, 前置フィルタ, 及 び積分器を含む拡大系の状態空間モデルは

$$
\begin{cases}\dot{x}_{s v}(t)=A_{s v} x_{s v}(t)+B_{s v} u_{s v}(t), & x_{s v}(t) \in R^{N \times 1} \\ y_{s v}(t)=C_{s v} x_{s v}(t) & y_{s v}(t) \in R\end{cases}
$$

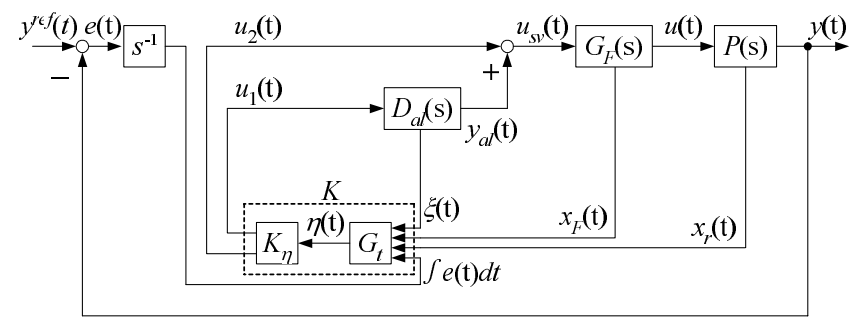

图 1 提案するサーボ系

Fig. 1. Proposed servo system
と表される。但し,$N=n+3$ とし，

$x_{s v}(t)=\left[\begin{array}{c}x_{r}(t) \\ x_{F}(t) \\ \int e(t) d t\end{array}\right], A_{s v}=\left[\begin{array}{ccc}\bar{A}_{r} & \bar{B}_{r} C_{F} & O_{n \times 1} \\ O_{2 \times n} & A_{F} & O_{2 \times 1} \\ -\bar{C}_{s v} & O_{1 \times 2} & 0\end{array}\right]$,

$B_{s v}=\left[\begin{array}{c}O_{n \times 1} \\ B_{F} \\ 0\end{array}\right], C_{s v}=\left[\begin{array}{ccc}\bar{C}_{r} & O_{1 \times 2} & 0\end{array}\right]$,

$\bar{C}_{s v}=\left[\begin{array}{llll}\bar{C}_{s v 1} & \bar{C}_{s v 2} & \cdots & \bar{C}_{s v N}\end{array}\right]$,

$A_{F}=\left[\begin{array}{ll}a_{f} & b_{f} \\ c_{f} & d_{f}\end{array}\right], B_{F}=\left[\begin{array}{l}0 \\ 1\end{array}\right], C_{F}=\left[\begin{array}{ll}1 & 0\end{array}\right]$

である。 $\bar{A}_{r} \in R^{n \times n}, \bar{B}_{r} \in R^{n \times 1}, \bar{C}_{r} \in R^{1 \times n}$ は可制御 正準系に变換した制御対象のパラメータ行列である。また， $A_{F} \in R^{2 \times 2}, B_{F} \in R^{2 \times 1}, C_{F} \in R^{1 \times 2}$ は, 前置フィルタの パラメータ行列で, $a_{f}, b_{f}, c_{f}, d_{f}$ はスカラの定数とする。

拡大系は元々， $\operatorname{rank} B_{s v}(=1)$ 個の入力を備えているた め低次元化か実現できる。乥こで (1) 式に対して, 次の正 則な行変換行列

$H=$ Block diag $\left[I_{n},\left[\begin{array}{cc}O_{1 \times 2} & 1 \\ I_{2} & O_{2 \times 1}\end{array}\right]\right]$

を施し，

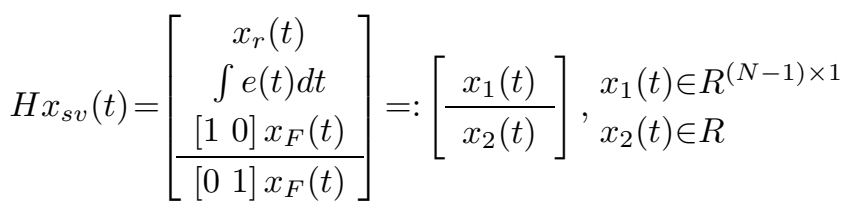

および

$$
\begin{aligned}
H A_{s v} H^{-1} & =\left[\begin{array}{ccc|c}
\bar{A}_{r} & O_{n \times 1} & \bar{B}_{r} & O_{n \times 1} \\
-\bar{C}_{s v} & 0 & 0 & 0 \\
O_{1 \times n} & 0 & a_{f} & b_{f} \\
\hline O_{1 \times n} & 0 & c_{f} & d_{f}
\end{array}\right] \\
& =:\left[\begin{array}{c|c}
A_{11} & A_{12} \\
\hline A_{21} & A_{22}
\end{array}\right]=: A \\
H B_{s v} & =\left[\begin{array}{c}
O_{(N-1) \times 1} \\
\hline 1
\end{array}\right]=: B
\end{aligned}
$$

のように変換する。ここで, 入力空間を拡大化するため, 次 のデュアルオブザーバ

$$
\left\{\begin{aligned}
\dot{\xi}(t) & =A_{D} \xi(t)+u_{1}(t) \\
y_{a l}(t) & =A_{a l} \xi(t)+J_{n} u_{1}(t), J_{n} \in R^{1 \times(N-1)} \\
u_{s v}(t) & =y_{a l}(t)+u_{2}(t)
\end{aligned}\right.
$$

を考える。但し，

$A_{D}:=A_{11}-A_{12} J_{n}, \quad A_{a l}:=A_{21}-A_{22} J_{n}+J_{n} A_{D}$

である。また,$J_{n}$ は $A_{D}$ を安定にするオブザーバゲインで ある。乥してさらに, 次の状態変数変換 


$$
\begin{gathered}
{\left[\begin{array}{c}
\eta_{1}(t) \\
\eta_{2}(t)
\end{array}\right]=G_{t}\left[\begin{array}{c}
x_{1}(t) \\
x_{2}(t) \\
\xi(t)
\end{array}\right]=: \eta(t), \ldots \ldots} \\
G_{t}=\left[\begin{array}{ccc}
I_{N-1} & O_{(N-1) \times 1} & I_{N-1} \\
O_{1 \times(N-1)} & 1 & -J_{n}
\end{array}\right]
\end{gathered}
$$

を施すと，拡大系とデュアルオブザーバとの併合系は

$$
\begin{aligned}
& {\left[\begin{array}{c}
\dot{\eta}(t) \\
\dot{\xi}(t)
\end{array}\right]=\left[\begin{array}{cc}
A & O_{N \times(N-1)} \\
O_{(N-1) \times N} & A_{D}
\end{array}\right]\left[\begin{array}{c}
\eta(t) \\
\xi(t)
\end{array}\right]} \\
& +\left[\begin{array}{c}
I_{N} \\
{\left[I_{N-1} O_{(N-1) \times 1}\right.}
\end{array}\right]\left[\begin{array}{l}
u_{1}(t) \\
u_{2}(t)
\end{array}\right]
\end{aligned}
$$

となり , 入力空間の次元が $N$ となって拡大化されているこ とがわかる。

〈2: 2〉内部安定性 図 1 に示すサーボ系において, 設 計仕樣 S.1) 及び S.2) を満足する制御則を考える。

いま，(4) 式の入力に対し，

$$
\left[\begin{array}{l}
u_{1}(t) \\
u_{2}(t)
\end{array}\right]=K_{\eta} \eta(t), K_{\eta}=:-A+\Lambda \text {. }
$$

なる状態フィードバック制御則を考える。但し，

$$
\Lambda=\left[\begin{array}{ccc|c}
\Lambda_{r} & O_{n \times 1} & \bar{B}_{r} & O_{n \times 1} \\
-\bar{C}_{s v} & \Lambda_{s} & 0 & 0 \\
O_{1 \times n} & 0 & \bar{a}_{f} & \bar{b}_{f} \\
\hline O_{1 \times n} & 0 & \bar{c}_{f} & \bar{d}_{f}
\end{array}\right]=:\left[\begin{array}{c|c}
\Lambda_{11} & \Lambda_{12} \\
\hline \Lambda_{21} & \Lambda_{22}
\end{array}\right]
$$

であり，

$$
\begin{aligned}
\Lambda_{s v} & =\left[\begin{array}{ccc}
\Lambda_{r} & {\left[\begin{array}{cc}
\bar{B}_{r} & O_{n \times 1}
\end{array}\right]} & O_{n \times 1} \\
O_{2 \times n} & \Lambda_{F} & O_{2 \times 1} \\
-\bar{C}_{s v} & O_{1 \times 2} & \Lambda_{s}
\end{array}\right], \\
\Lambda_{r} & =\left[\begin{array}{cc}
\Lambda_{r 1} & O_{(n-1) \times 1} \\
O_{1 \times(n-1)} & \Lambda_{r 2}
\end{array}\right], \Lambda_{F}=\left[\begin{array}{cc}
\bar{a}_{f} & \bar{b}_{f} \\
\bar{c}_{f} & \bar{d}_{f}
\end{array}\right]
\end{aligned}
$$

を $\Lambda=H \Lambda_{s v} H^{-1}$ により変換したものである。 $\Lambda_{r}$ は安定 な対角行列とし， $\Lambda_{s}$ は $\operatorname{Re} \Lambda_{s}<0$ を満足する定数である。 弚れゆえ， $\Lambda_{s v}$ は安定行列である。また， $\Lambda_{F}$ は所望の前 置フィルタの特性を得るように設計される安定な行列とす る。このとき，(5) 式を (4) 式に代入して

$$
\left[\begin{array}{c}
\dot{\eta}(t) \\
\dot{\xi}(t)
\end{array}\right]=\left[\begin{array}{cc}
\Lambda & O_{N \times(N-1)} \\
{\left[-A_{11}+\Lambda_{11}-A_{12}+\Lambda_{12}\right]} & A_{D}
\end{array}\right]\left[\begin{array}{l}
\eta(t) \\
\xi(t)
\end{array}\right]
$$

となる。ゆえに

$0=\lim _{t \rightarrow \infty}\left[\begin{array}{l}\eta(t) \\ \xi(t)\end{array}\right]=\lim _{t \rightarrow \infty}\left[\left[\begin{array}{cc}G_{t} \\ O_{(N-1) \times N} & I_{N-1}\end{array}\right]\right]\left[\begin{array}{c}H x_{s v}(t) \\ \xi(t)\end{array}\right]$ より

$$
\lim _{t \rightarrow \infty} x_{s v}(t)=0
$$

となってサーボが達成され, 設計仕樣 S.1) 及びS.2) の内 部安定化が満足される。
〈2. 3〉 補償器と前置フィルタの分離

(3) 式及び (5) 式より状態フィードバックゲイン $K$ を

$$
(-A+\Lambda) G_{t}=\left[\begin{array}{llll}
K_{r} & K_{s} & K_{F} & K_{\xi}
\end{array}\right]=: K .
$$

として $, K_{r} \in R^{N \times n}, K_{s} \in R^{N \times 1}, K_{F} \in R^{N \times 2}, K_{\xi} \in$ $R^{N \times(N-1)}$ を計算する。

$$
\begin{aligned}
-A+\Lambda & =\left[\begin{array}{ccc|c}
-\bar{A}_{r}+\Lambda_{r} & O_{n \times 1} & O_{n \times 1} & O_{n \times 1} \\
O_{1 \times n} & \Lambda_{s} & 0 & 0 \\
O_{1 \times n} & 0 & -a_{f}+\bar{a}_{f} & -b_{f}+\bar{b}_{f} \\
O_{1 \times n} & 0 & -c_{f}+\bar{c}_{f} & -d_{f}+\bar{d}_{f}
\end{array}\right] \\
= & :\left[Q_{1} \mid Q_{2}\right]
\end{aligned}
$$

とする。但し $, Q_{1} \in R^{N \times(N-1)}, Q_{2} \in R^{N \times 1}$ である。こ のとき $(6)$ 式は ,

$$
\begin{aligned}
K & =(-A+\Lambda) G_{t} \\
& =\left[\begin{array}{l|l}
Q_{1} & Q_{2}
\end{array}\right]\left[\begin{array}{ccc}
I_{N-1} & O_{(N-1) \times 1} & I_{N-1} \\
\hline O_{1 \times(N-1)} & 1 & -J_{n}
\end{array}\right] \\
& =\left[\begin{array}{lll}
Q_{1} & Q_{2} & Q_{1}-Q_{2} J_{n}
\end{array}\right]
\end{aligned}
$$

と計算される。よって, 各状態フィードバックゲインは,

$$
\begin{aligned}
& K_{r}=\left[\left(-\bar{A}_{r}+\Lambda_{r}\right)^{T} O_{n \times 1} O_{n \times 1} O_{n \times 1}\right]^{T}, \\
& K_{s}=\left[\begin{array}{llll}
O_{1 \times n} & \Lambda_{s} & 0 & 0
\end{array}\right]^{T}, \\
& K_{F}=\left[\begin{array}{cc}
O_{n \times 1} & O_{n \times 1} \\
0 & 0 \\
-a_{f}+\bar{a}_{f} & -b_{f}+\bar{b}_{f} \\
-c_{f}+\bar{c}_{f} & -d_{f}+\bar{d}_{f}
\end{array}\right] \text {, } \\
& K_{\xi}=Q_{1}-Q_{2} J_{n}=:\left[\begin{array}{c}
K_{\xi}^{1} \\
K_{\xi}^{2}
\end{array}\right]
\end{aligned}
$$

となる。但し , $J_{n}=\left[\begin{array}{lll}J_{n 1} & J_{n 2} & J_{n 3}\end{array}\right], J_{n 1} \in R^{1 \times n}$, $J_{n 2} \in R, J_{n 3} \in R$ として

$K_{\xi}^{1}=$

$\left[\begin{array}{ccc}-\bar{A}_{r}+\Lambda_{r} & O_{n \times 1} & O_{n \times 1} \\ O_{1 \times n} & \Lambda_{s} & 0 \\ \left(b_{f}-\bar{b}_{f}\right) J_{n 1} & \left(b_{f}-\bar{b}_{f}\right) J_{n 2} & -a_{f}+\bar{a}_{f}+\left(b_{f}-\bar{b}_{f}\right) J_{n 3}\end{array}\right]$, $K_{\xi}^{2}=$

$\left[\left(d_{f}-\bar{d}_{f}\right) J_{n 1},\left(d_{f}-\bar{d}_{f}\right) J_{n 2},-c_{f}+\bar{c}_{f}+\left(d_{f}-\bar{d}_{f}\right) J_{n 3}\right]$

である。また $, K_{\xi}^{1} \in R^{(N-1) \times(N-1)}, K_{\xi}^{2} \in R^{1 \times(N-1)} て ゙$ ある。

前置フィルタの所望の遮断特性を得るため, デュアルオ ブザーバと前置フィルタの伝達関数を見かけ上分離しよう。

いま，前置フィルタの状態空間モデルは

$$
\left\{\begin{aligned}
\dot{x}_{F}(t) & =A_{F} x_{F}(t)+B_{F} u_{s v}(t) \\
u(t) & =C_{F} x_{F}(t)
\end{aligned}\right.
$$

であり，(2) 式を代入すれば, 弚の状態方程式は 
$\dot{x}_{F}(t)=A_{F} x_{F}(t)+B_{F} A_{a l} \xi(t)+B_{F}\left[\begin{array}{ll}J_{n} & 1\end{array}\right]\left[\begin{array}{l}u_{1}(t) \\ u_{2}(t)\end{array}\right]$

となる。ところで (6) 式より (5) 式は

$$
\left[\begin{array}{l}
u_{1}(t) \\
u_{2}(t)
\end{array}\right]=\left[\begin{array}{llll}
K_{r} & K_{s} & K_{F} & K_{\xi}
\end{array}\right]\left[\begin{array}{c}
x_{r}(t) \\
\int e(t) d t \\
x_{F}(t) \\
\xi(t)
\end{array}\right] .
$$

と表せるが ,ここで便宜上

$$
q(t)=\left[\begin{array}{ll}
K_{r} & K_{s}
\end{array}\right]\left[\begin{array}{c}
x_{r}(t) \\
\int e(t) d t
\end{array}\right]
$$

とおくと

$$
\begin{aligned}
\dot{x}_{F}(t)= & \left(A_{F}+B_{F}\left[\begin{array}{ll}
J_{n} & 1
\end{array}\right] K_{F}\right) x_{F}(t) \\
& +\left(A_{a l}+\left[\begin{array}{ll}
J_{n} & 1
\end{array}\right] K_{\xi}\right) \xi(t)+\left[\begin{array}{ll}
J_{n} & 1
\end{array}\right] q(t)
\end{aligned}
$$

となる。いま, 前置フィルタの入力を

$\bar{q}(t)=\left(A_{a l}+\left[\begin{array}{ll}J_{n} & 1\end{array}\right] K_{\xi}\right) \xi(t)+\left[\begin{array}{ll}J_{n} & 1\end{array}\right] q(t)$

とおくと, $\bar{q}(t)$ から $u(t)$ の伝達関数を $\bar{G}_{F}(s)$ とすれば,

$$
\bar{G}_{F}(s)=\left[\begin{array}{c|c}
A_{F}+B_{F}\left[\begin{array}{ll}
J_{n} & 1
\end{array}\right] K_{F} & B_{F} \\
\hline C_{F} & 0
\end{array}\right] .
$$

となる。一方 , デュアルオブザーバの状態方程式は $(2)$ 式 及び $(8)$ 式 $u_{1}(t)$ より，

$$
\begin{aligned}
& \dot{\xi}(t)=A_{D} \xi(t) \\
& +\left[\begin{array}{ll}
I_{N-1} & O_{(N-1) \times 1}
\end{array}\right]\left\{K_{F} x_{F}(t)+K_{\xi} \xi(t)+q(t)\right\} \\
& =\left(A_{D}+K_{\xi}^{1}\right) \xi(t) \\
& +\left[\begin{array}{ll}
I_{N-1} & O_{(N-1) \times 1}
\end{array}\right]\left\{K_{F} x_{F}(t)+q(t)\right\} \cdots
\end{aligned}
$$

となる。ここで

$$
\bar{a}_{f}=a_{f}, \bar{b}_{f}=b_{f}
$$

とすると

$$
\left[\begin{array}{ll}
I_{N-1} & O_{(N-1) \times 1}
\end{array}\right] K_{F}=O_{(N-1) \times 1}
$$

より (10) 式は

$$
\dot{\xi}(t)=\left(A_{D}+K_{\xi}^{1}\right) \xi(t)+\left[\begin{array}{ll}
I_{N-1} & O_{(N-1) \times 1}
\end{array}\right] q(t)
$$

と表される。よって $q(t)$ から $\bar{q}(t)$ の伝達関数を $\bar{D}_{a l}(s)$ と すれば，

$$
\bar{D}_{a l}(s)=\left[\begin{array}{c|c}
A_{D}+K_{\xi}^{1} & {\left[\begin{array}{cc}
I_{N-1} O_{(N-1) \times 1}
\end{array}\right]} \\
\hline A_{a l}+\left[\begin{array}{ll}
J_{n} & 1
\end{array}\right] K_{\xi} & {\left[\begin{array}{ll}
J_{n} & 1
\end{array}\right]}
\end{array}\right]
$$

となる。このようにデュアルオブザーバと前置フィルタと の併合系が見かけ上 $\bar{D}_{a l}(s)$ と $\bar{G}_{F}(s)$ との積により記述さ れ，図 1 は図 2 に示すように表される。デュアルオブザー バと前置フィルタとが見かけ上分離されているので, 各々 の補償器の設計を見通しよく行えることが可能となる。

〈2. 4〉 制御系設計 $\quad \bar{G}_{F}(s)$ のシステム行列は, (11)

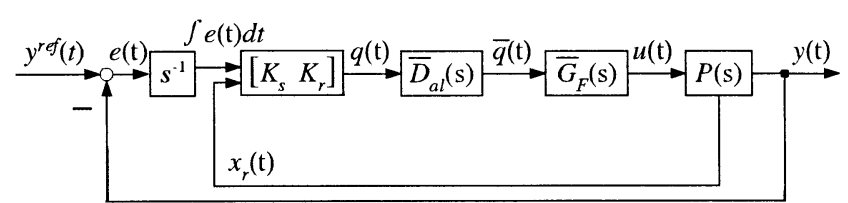

图 2 デュアルオブザーバを併合したサーボ系

Fig. 2. Servo system including dual observer

\section{式を考慮して}

$$
A_{F}+B_{F}\left[\begin{array}{ll}
J_{n} & 1
\end{array}\right] K_{F}=\left[\begin{array}{cc}
a_{f} & b_{f} \\
\bar{c}_{f} & \bar{d}_{f}
\end{array}\right]=\Lambda_{F} \cdots
$$

となるため, 設計パラメータ $\Lambda_{F}$ を適当に設定することに より，所望のフィルタ特性が得られる。問題は (11) 式の条 件の下で

[1] $A_{D}$ の特性根 $\operatorname{Re} \lambda\left(A_{D}\right)=-\operatorname{Re} \lambda_{d i}<0(i=1, \cdots$,

$N-1)$ を複素左半平面の所望の領域に配置する

[2] $A_{D}+K_{\xi}^{1}$ の特性根を安定な領域に配置する

$[3]$ 所望のフィルタ特性を有する $\Lambda_{F}$ を設計する

パラメータ $a_{f}, b_{f}, \bar{c}_{f}, \bar{d}_{f}, J_{n}, \Lambda_{r}, \Lambda_{s}, \lambda_{d i}(i=$

$1, \ldots, N-1)$ を求めることである。

まず，上記 $[\mathbf{1}]$ 及び $[\mathbf{2}]$ を考えよう。各行列を計算すると，

$$
\begin{aligned}
A_{D} & =A_{11}-A_{12} J_{n} \\
& =\left[\begin{array}{ccc}
\bar{A}_{r} & O_{n \times 1} & \bar{B}_{r} \\
-\bar{C}_{s v} & 0 & 0 \\
-b_{f} J_{n 1} & -b_{f} J_{n 2} & a_{f}-b_{f} J_{n 3}
\end{array}\right] \ldots(13) \\
A_{D} & +K_{\xi}^{1}=\left[\begin{array}{ccc}
\Lambda_{r} & O_{n \times 1} & \bar{B}_{r} \\
-\bar{C}_{s v} & \Lambda_{s} & 0 \\
-b_{f} J_{n 1} & -b_{f} J_{n 2} & a_{f}-b_{f} J_{n 3}
\end{array}\right]
\end{aligned}
$$

である。このとき，(13)式より少なくとも

$$
\operatorname{tr} \bar{A}_{r}+a_{f}-b_{f} J_{n 3}=-\sum_{i=1}^{N-1} \lambda_{d i} .
$$

でなければならない。(15) 式を（14）式に代入すると，行 列 $A_{D}+K_{\xi}^{1}$ の特性方程式

$$
\begin{aligned}
& \left|s I_{N-1}-A_{D}-K_{\xi}^{1}\right|= \\
& \left|s I_{n-1}-\Lambda_{r 1}\right|\left|\begin{array}{ccc}
s-\Lambda_{r 2} & 0 & -1 \\
-\bar{C}_{s v N} & s-\Lambda_{s} & 0 \\
b_{f} J_{n 1 n} & b_{f} J_{n 2} & s-\rho_{1}
\end{array}\right|=0 \cdots
\end{aligned}
$$

の根が安定になるようにパラメータを決定する必要がある。 但し，

$$
\begin{aligned}
\bar{C}_{s v N} & =:-\bar{C}_{s v}\left[O_{1 \times(N-1)} 1\right]^{T}, \\
b_{f} J_{n 1 n} & =: b_{f} J_{n 1}\left[\begin{array}{ll}
O_{1 \times(n-1)} & 1
\end{array}\right]^{T}, \\
\rho_{1} & =:-\left(\sum_{i=1}^{N-1} \lambda_{d i}+\operatorname{tr} \bar{A}_{r}\right)
\end{aligned}
$$

である。 
いま，簡単のため制御対象 $\left(\bar{A}_{r}, \bar{B}_{r}, \bar{C}_{r}\right)$ の相対次数が 2 次以上 $\left(\bar{C}_{s v N}=0\right)$ の場合を考えると，

$$
\begin{aligned}
& \left|\begin{array}{ccc}
s-\Lambda_{r 2} & 0 & -1 \\
0 & s-\Lambda_{s} & 0 \\
b_{f} J_{n 1 n} & b_{f} J_{n 2} & s-\rho_{1}
\end{array}\right| \\
= & \left(s-\Lambda_{s}\right)\left\{s^{2}-\left(\Lambda_{r 2}+\rho_{1}\right) s+\Lambda_{r 2} \rho_{1}+b_{f} J_{n 1 n}\right\}
\end{aligned}
$$

となることから，このとき安定性の条件は

$$
\Lambda_{r 2}+\rho_{1}<0, \Lambda_{r 2} \rho_{1}>-\rho_{2} .
$$

となる。このとき,$\left|s I_{N-1}-A_{D}\right|=\prod_{i=1}^{N-1}\left(s+\lambda_{d i}\right)$ の係 数比較より, $\rho_{2}$ は

$$
\rho_{2}=: b_{f} J_{n 1 n}=\sum_{i=1}^{N-2} \sum_{j=i+1}^{N-1} \lambda_{d i} \lambda_{d j}-\rho_{1} \operatorname{tr} \bar{A}_{r}-a_{r(n-1)}
$$

である (相対次数が 2 次未満の場合の定式化は付録 1 を参 照のこと)。但し, $a_{r(n-1)}$ は $\bar{A}_{r}$ の特性多項式の $n-2$ 次 の項の係数である。すなわち, (15) 式及び (17) 式の条件を 満足するようにデュアルオブザーバの特性根 $-\operatorname{Re} \lambda_{d i}<0$ 及び $\operatorname{Re} \Lambda_{r 2}<0$ を選ぶこととなる。また， $\Lambda_{r 1}$ は適当な安 定な対角行列， $\Lambda_{s}$ は $\operatorname{Re} \Lambda_{s}<0$ を満足する適当な定数を 選び， $\lambda_{d i}(i=1, \cdots, \quad N-1)$ は準ニュートンアルゴリ ズムを用いて最適化を図る。

次に，上記 $[3]$ を考えよう。いま，所望の前置フィルタを

$$
\bar{G}_{F}(s)=\frac{g_{F}}{s^{2}+2 \zeta_{F}\left(2 \pi f_{F}\right) s+\left(2 \pi f_{F}\right)^{2}}
$$

とすると，(9) 式及び (12) 式より，

$$
\bar{G}_{F}(s)=\left[\begin{array}{c|c}
\Lambda_{F} & B_{F} \\
\hline C_{F} & 0
\end{array}\right]
$$

であるから，上記 2 つの式を係数比較すると，前置フィル タの各パラメータは，

$$
b_{f}=g_{F}, \bar{c}_{f}=-\frac{1}{g_{F}}\left\{a_{f}\left(a_{f}+2 \zeta_{F}\left(2 \pi f_{F}\right)\right)+\left(2 \pi f_{F}\right)^{2}\right\},
$$

$\bar{d}_{f}=-a_{f}-2 \zeta_{F}\left(2 \pi f_{F}\right)$

により決定される。但し， $a_{f}$ は任意定数である。

\section{3. 数值シミュレーション}

2 つの柔軟構造物 (1 リンク・フレキシブルアームと 1 リンク・フレキシブル倒立振子-台車系) を応用例に挙げ る。光れ光れにおいてまずモデル化を行い，次に従来の状 態フィードバックベースの最適制御による手法 (Case1) と 比較して, 最適化アルゴリズムにより探索した設計パラメー タを用いた提案するサーボ法 (Case2) が有効であることを 数值シミュレーションにより検証する。

〈3. 1〉応用例 11 リンク・フレキシブルアーム

〈3.1.1〉 モデリング (応用例 1) 图 3 のような水平 面内で回転する 1 リンク・フレキシブルアームの位置決め 制御を考える。但し，アームは Bernoulli-Euler 梁である と仮定し, 非線形項（遠心力やコリオリカ）は無視できる ものとする。さらに, 根元は八ブで固定され, 先端に荷重 $m_{p}$ を有し, 角度 $\theta(t)$ のみ測定可能とする。ハミルトン原 理より,

$$
\begin{aligned}
& J_{\theta} \ddot{\theta}(t)+D_{\theta} \dot{\theta}(t) \\
& \quad-\left\{E_{m}(r)+m_{p} L \Phi_{m}(L)\right\}^{T} \ddot{P}_{m}(t)=\tau(t), \cdots \\
& \rho_{L} A_{L}\left\{\ddot{P}_{m}(t)+\Gamma_{m} \dot{P}_{m}(t)+\Lambda_{m} P_{m}(t)\right\} \\
& \quad-\left\{E_{m}(r)+m_{p} L \Phi_{m}(L)\right\} \ddot{\theta}(t)=O_{m \times 1} \cdots
\end{aligned}
$$

を得る。但し，

$$
\begin{gathered}
J_{\theta}=J_{0}+\frac{\rho_{L} A_{L} L^{3}}{3}+m_{p} L^{2}, \\
E_{m}(r)=\left[e_{1}(r), \cdots, e_{i}(r), \cdots, e_{m}(r)\right]^{T}, \\
\cdots \cdots \cdots \cdots \cdots \cdots \cdots \cdot(20) \\
\Phi_{m}(L)=\left[\phi_{1}(L), \cdots, \phi_{i}(L), \cdots, \phi_{m}(L)\right]^{T} \\
\cdots \cdots \cdots \cdots \cdots \cdots \cdot(21) \\
\Lambda_{m}=\operatorname{diag}\left[\lambda_{1}, \cdots, \lambda_{i}, \cdots, \lambda_{m}\right], \cdots \cdots \cdots,(22) \\
\Gamma_{m}=2 \zeta_{L} \Lambda_{m}, P_{m}(t)=\left[p_{1}(t), \cdots, p_{i}(t), \cdots, p_{m}(t)\right]^{T}
\end{gathered}
$$

とする(詳細は付録 2 を参照のこと)。(18) 式は回転方程式， (19) 式は $m$ 次元の振動方程式を表す。 $L$ は梁の全長， $\rho_{L}$ は梁の面密度, $A_{L}$ は梁の断面積 (厚み $W_{L} \times$ 幅 $T_{L}$ ), $E_{L}$ は梁のヤング率, $I_{L}$ は梁の断面 2 次モーメント, $w(r, t)$ は 梁上の任意の点における弾性変位, $\tau(t)$ はモータの駆動卜 ルクとおく。また， $J_{0}$ はモータのロータと八ブの合成慣性 モーメント， $D_{\theta}$ はロータ回りの粘性摩擦係数, $e_{i}(r)$ は回 転と振動の慣性に関するカップリング係数， $\phi_{i}(L)$ は先端 での振動の固有関数, $p_{i}(t)$ は振動のモード変数, $\lambda_{i}$ は振 動の固有値， $\zeta_{L}$ は振動の減衰係数である。

本論文では，振動モードを $m=3$ まで考え，(18) 式及び (19) 式より剛体モード及び 1 st 振動モードからなる $n=4$ の線形な状態空間モデル

$$
\left\{\begin{array}{rl}
\dot{x}_{p}(t) & =A_{p} x_{p}(t)+B_{p} u(t), \\
y_{p}(t) & =C_{p} x_{p}(t)
\end{array}, \begin{array}{rl}
x_{p}(t) & \in R^{4 \times 1} \\
y_{p}(t), u(t) & \in R
\end{array}\right.
$$

を設計モデルとして用いる ${ }^{(12)}$ 。但し，

$$
\begin{aligned}
& x_{p}=\left[\begin{array}{llll}
\theta(t) & p_{1}(t) & \dot{\theta}(t) & \dot{p}_{1}(t)
\end{array}\right]^{T}, \\
& A_{p}=\left[\begin{array}{cc}
O_{2} & I_{2} \\
-M_{p}^{-1} K_{p} & -M_{p}^{-1} D_{p}
\end{array}\right], B_{p}=\left[\begin{array}{c}
O_{2 \times 1} \\
M_{p}^{-1} T_{p}
\end{array}\right] \text {, }
\end{aligned}
$$

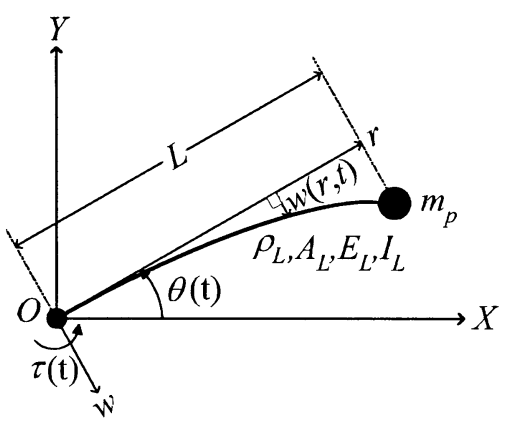

図 3 1 リンク・フレキシブルアーム

Fig. 3. 1 link flexible arm 
表 1 物理パラメータ

Table 1. Physical parameters

\begin{tabular}{c|c||c|c}
\hline \hline Parameter & Value & Parameter & Value \\
\hline \hline$L[\mathrm{~m}]$ & 1.0 & $A_{L}\left[\mathrm{~m}^{2}\right]$ & $2.50 \times 10^{-4}$ \\
\hline$W_{L}[\mathrm{~m}]$ & $5.00 \times 10^{-3}$ & $T_{L}[\mathrm{~m}]$ & $5.00 \times 10^{-2}$ \\
\hline$E_{L}\left[\mathrm{~N} / \mathrm{m}^{2}\right]$ & $7.05 \times 10^{10}$ & $I_{L}[\mathrm{~m}]$ & $5.21 \times 10^{-10}$ \\
\hline$\rho_{L}\left[\mathrm{~kg} / \mathrm{m}^{3}\right]$ & 2690 & $m_{p}[\mathrm{~kg}]$ & 0.1 \\
\hline$J_{0}\left[\mathrm{kgm}{ }^{2}\right]$ & 0.4 & $D_{\theta}[1 / \mathrm{s}]$ & 0.01 \\
\hline$\zeta_{L}$ & $1.00 \times 10^{-5}$ & $f_{1}[\mathrm{~Hz}]$ & 3.3 \\
\hline$f_{2}[\mathrm{~Hz}]$ & 22.0 & $f_{3}[\mathrm{~Hz}]$ & 63.9 \\
\hline \hline
\end{tabular}

$$
\begin{aligned}
C_{p} & =\left[\begin{array}{cc}
1 & O_{1 \times 3}
\end{array}\right], \\
M_{p} & =\left[\begin{array}{cc}
J_{\theta} & -\left\{e_{1}(r)+m_{p} L \phi_{1}(L)\right\} \\
-\left\{e_{1}(r)+m_{p} L \phi_{1}(L)\right\} & \rho_{L} A_{L}
\end{array}\right], \\
D_{p} & =\left[\begin{array}{cc}
D_{\theta} & 0 \\
0 & \rho_{L} A_{L}\left(2 \zeta_{L} \lambda_{1}\right)
\end{array}\right], \\
K_{p} & =\left[\begin{array}{cc}
0 & 0 \\
0 & \rho_{L} A_{L} \lambda_{1}
\end{array}\right], T_{p}=\left[\begin{array}{l}
1 \\
0
\end{array}\right]
\end{aligned}
$$

とする。ここで, 設計の見通しをよくするため，(23) 式を 可制御正準系に変換する。(23) 式の伝详関数を

$$
P(s)=\frac{c_{r 4} s^{3}+c_{r 3} s^{2}+c_{r 2} s+c_{r 1}}{s^{4}+a_{r 4} s^{3}+a_{r 3} s^{2}+a_{r 2} s+a_{r 1}} \cdots
$$

と表し, 次の可制御変換行列

$$
T_{c}=\left[\begin{array}{llll}
B_{p} & A_{p} B_{p} & A_{p}^{2} B_{p} & A_{p}^{3} B_{p}
\end{array}\right]\left[\begin{array}{cccc}
a_{r 2} & a_{r 3} & a_{r 4} & 1 \\
a_{r 3} & a_{r 4} & 1 & 0 \\
a_{r 4} & 1 & 0 & 0 \\
1 & 0 & 0 & 0
\end{array}\right]
$$

を用いて (23) 式を変換すると，

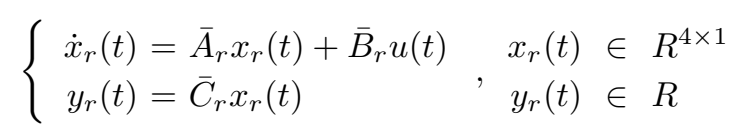

を得る。但し，

$$
\begin{aligned}
& x_{r}(t)=T_{c}^{-1} x_{p}(t) \\
& \bar{A}_{r}=T_{c}^{-1} A_{p} T_{c}=\left[\begin{array}{cccc}
O_{3 \times 1} & & I_{3} & \\
-a_{r 1} & -a_{r 2} & -a_{r 3} & -a_{r 4}
\end{array}\right], \\
& \text {......... } \\
& \bar{B}_{r}=T_{c}^{-1} B_{p}=\left[\begin{array}{ll}
O_{1 \times 3} & 1
\end{array}\right]^{T}, \\
& \bar{C}_{r}=C_{p} T_{c}=\left[\begin{array}{llll}
c_{r 1} & c_{r 2} & c_{r 3} & c_{r 4}
\end{array}\right]
\end{aligned}
$$

である。このときの物理パラメータを表 1 に示す。

〈3.1.2〉 サーボ問題 (応用例 1) 具体的には, 次の サーボ問題を考え，以下に示す 2 つのケースを比較する。 サーボ問題: $\quad t=1[\mathrm{~s}]$ でアームの角度 $\theta(t)$ を目標值 $0.1[\mathrm{rad}]$ のステップ信号に追従
表 2 設計パラメータ

Table 2. Design parameters

\begin{tabular}{c|c||c|c}
\hline \hline Parameter & Value & Parameter & Value \\
\hline \hline$f_{F}$ & 20.0 & $\lambda_{d 1}$ & 8.8 \\
$\zeta_{F}$ & 1.0 & $\lambda_{d 2}$ & 5.1 \\
$g_{F}$ & $(2 \pi 20.0)^{2}$ & $\lambda_{d 3}$ & 154.3 \\
$a_{f}$ & 1.0 & $\lambda_{d 4}$ & 2.0 \\
$b_{f}$ & 987.0 & $\lambda_{d 5}$ & 1.3 \\
$\bar{c}_{f}$ & -4.1 & $\lambda_{d 6}$ & 1.3 \\
\cline { 2 - 2 } $\bar{d}_{f}$ & -126.7 & & 57.9 \\
\hline$\Lambda_{r 1}$ & $\operatorname{diag}[-1.0,-2.0,-3.0]$ & & 47.2 \\
$\Lambda_{r 2}$ & -73.5 & $J_{n}$ & -112.3 \\
$\Lambda_{s}$ & -5.0 & & 2.3 \\
\hline $\mathrm{R}^{r e f}$ & 1.4 & & $-2.4 \times 10^{-2}$ \\
$\mathrm{I}^{r e f}$ & 0.9 & & $1.8 \times 10^{-1}$ \\
\hline \hline
\end{tabular}

Case1 周波数依存型最適サーボ系 ${ }^{(6)}$ (以降, 従来法)を 用いて設計する。評価関数

$$
J_{q}=\int_{0}^{\infty}\left\{\dot{x}_{s v}(t)^{T} Q_{s v} \dot{x}_{s v}(t)+\dot{u}^{2}(t)\right\} d t,
$$

$Q_{s v}=\operatorname{diag}\left[\begin{array}{llllll}5 & 1 & 1 & 1 & 0 & 0\end{array}\right]$

を最小にする問題とし，产の安定化制御則から得られる 最適制御入力

$u(t)=-\left[\begin{array}{lll}k_{r} & k_{F} & k_{s}\end{array}\right] x_{s v}(t) \cdots$

を用いる。但し， $k_{r} \in R^{1 \times 4}, k_{F} \in R^{1 \times 2}, k_{s} \in R$ ， $x_{s v}(t)=\left[\hat{x}_{p}^{T}(t) x_{F}^{T}(t) \int e(t) d t\right]^{T}$ とし, $\hat{x}_{p}(t)$ は同一次 元オブザーバ(極 $[-100,-200,-300,-400])$ によって推定す る。また, 前置フィルタの遮断特性は, 2nd 振動モード 以上を抑制する為, $f_{F}=20.0[\mathrm{~Hz}], \zeta_{F}=1.0$ とする。

Case2 提案法を用いて設計する。設計パラメータを表 2 に示す。なお，同一次元オブザーバの極は Case1 と同 樣である。また , デュアルオブザーバの特性根 $-\operatorname{Re} \lambda_{d i}<$ $0(i=1, \cdots, 6)$ の複素平面上の存在位置と過渡特性の関 係に着目し，次のような評価関数

$$
\begin{aligned}
J_{a}= & \frac{\left|\operatorname{Im}\left(-\lambda_{d i}^{i m a x}\right)\right|}{\left|\operatorname{Re}\left(-\lambda_{d i}^{i m a x}\right)\right|}+\frac{\left|\operatorname{Im}\left(-\lambda_{d i}^{r m i n}\right)\right|}{\left|\operatorname{Re}\left(-\lambda_{d i}^{r m i n}\right)\right|}+\left\{\mathrm{R}^{r e f}\right. \\
& \left.-\left|\operatorname{Re}\left(-\lambda_{d i}^{r m i n}\right)\right|\right\}^{2}+\left\{\mathrm{I}^{\text {ref }}-\left|\operatorname{Im}\left(-\lambda_{d i}^{i m i n}\right)\right|\right\}^{2}
\end{aligned}
$$

を定め, 乥れを最小とするよう準ニュートンアルゴリズム を用いて最適化を図る。但し $,-\lambda_{d i}^{i m a x},-\lambda_{d i}^{r m i n},-\lambda_{d i}^{i m i n}$ は各々デュアルオブザーバの，虚部の絶対值が最も大きい 特性根, 実部の絶対値が最も小さい特性根, 虚部の絶対 值が最も小さい特性根を表し, 時間が十分経過後も過渡 状態が最後まで残る代表特性根である。また , $\mathrm{R}^{r e f}>0$, $I^{r e f}>0$ は目標とする特性根である。

一般に, 速応性と減衰性の間にトレードオフの関係が あることから，図 4 に示す複素左半平面の網掛け領域内 $\left(\delta=37^{\circ} \sim 53^{\circ}\right)$ に特性根を配置するのか望ましいことが 知られている ${ }^{(13)}$ 。(33) 式右辺第 1 項及び第 2 項は, 相 対的に実部及び虚部の比を小さくして望ましい領域に収 まるよう定める。このことは速応性と減衰性を改善する ことに対応する (図中の矢印(1)と(2))。(33) 式右辺第 3 項 及び第 4 項は, 原点近傍の特性根 $-\lambda_{d i}^{r m i n}$ 及び $-\lambda_{d i}^{i m i n}$ を目標の特性根に漸近するよう重み付けを行う。このこ とは原点近傍の特性根が原点から大きく離れて配置され 


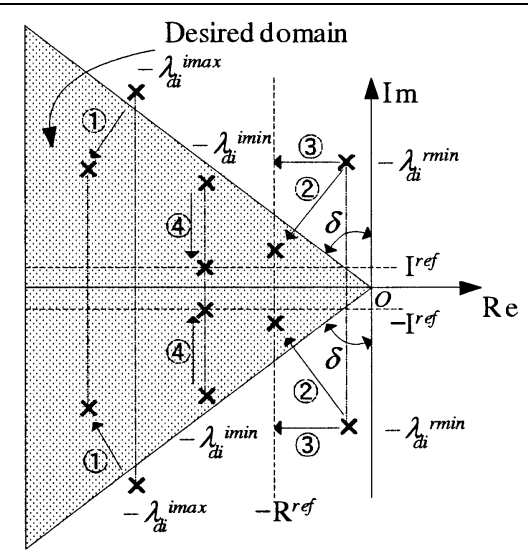

図 4 デュアルオブザーバの代表特性根の極指定

Fig. 4. Pole assignment of typical characteristic roots of dual observer

ると過渡特性が劣化する可能性があり，これを回避する ためである (図中の矢印(3)と(4)に対応)。

図 5 及び図 6 に, 各々従来法及び提案法によるシミュレー ション結果を示す。各 Case の (a), (b), (c), 及び (d) は， 各々アームの角度, 1 st 振動モード, 2 nd 振動モード, 及び 3rd 振動モードの時間応答である。

Case1では, 設計仕樣 S.1) 及びS.2) を実現しているが， 弾性振動の減衰性が悪い応答となっている。特に，2nd 振 動モードの振動が残っている。このとき, 設定した所望の 前置フィルタの遮断特性 $\left(f_{F}, \zeta_{F}\right)$ と実際に設計された前 置フィルタの遮断特性 $\left(f_{F}^{\prime}, \zeta_{F}^{\prime}\right)$ の関係が

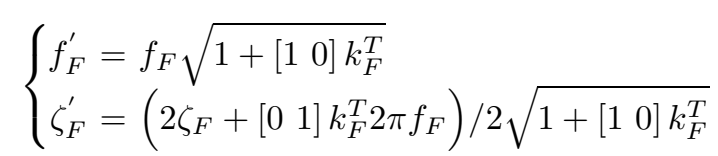

と表される。計算すると $f_{F}^{\prime}=20.88[\mathrm{~Hz}], \zeta_{F}^{\prime}=1.07$ となる ことから，遮断特性を任意に指定できず弾性振動の減衰性 が劣化しスピルオーバ現象が生じた為である。なお，重み $Q_{s v}$ の調整次第で $f_{F}^{\prime} \approx f_{F}, \zeta_{F}^{\prime} \approx \zeta_{F}$ となるが, 厳密に一 致させることはできない。

Case2 も同樣に設計仕樣 S.1) 及び S.2) を実現してい る。さらに, 過渡特性 (速応性及び減衰性) は Case1 と比 較して良好であることから，評価関数による最適化及び前 置フィルタの効果が確認できる。以上の結果から，提案す る制御系の有効性が示された。

〈3. 2〉応用例 21 リンク・フレキシブル倒立振子-台車系

〈3. 2. 1〉 モデリング (応用例 2) 图 7 のような 1 リ ンク・フレキシブル倒立振子-台車系の位置決め制御を考え る。但し，振子は Bernoulli-Euler 梁であると仮定し，平衡 点近傍で倒立するので非線形項（遠心力やコリオリカ）は 無視できるものとする。さらに, 根元は剛体振子で固定さ れ, 先端に荷重 $m_{p}$ を有し, 台車の位置 $X(t)$ 及び振子の 角度 $\theta(t)$ のみ測定可能とする。八ミルトン原理より，

$$
\begin{aligned}
& \ddot{X}(t)+\zeta_{c} \dot{X}(t)=\xi_{c} V^{r e f}(t) \ldots \ldots \ldots \ldots \ldots \\
& m_{\theta} \ddot{X}(t)+J_{\theta} \ddot{\theta}(t)+D_{\theta} \dot{\theta}(t)-m_{\theta} g \theta(t) \\
& \quad+\left\{E_{m}(r)+m_{p}(l+L) \Phi_{m}(L)\right\}^{T} \ddot{P}_{m}(t) \\
& \quad-\left\{H_{m}(r)+m_{p} \Phi_{m}(L)\right\}^{T} g P_{m}(t)=0,
\end{aligned}
$$

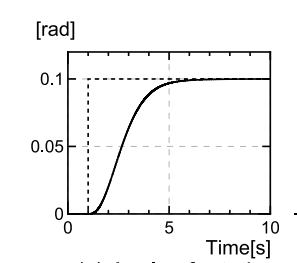

$\left[1 \times 10^{-7}\right]$ (a) Angle of rotation
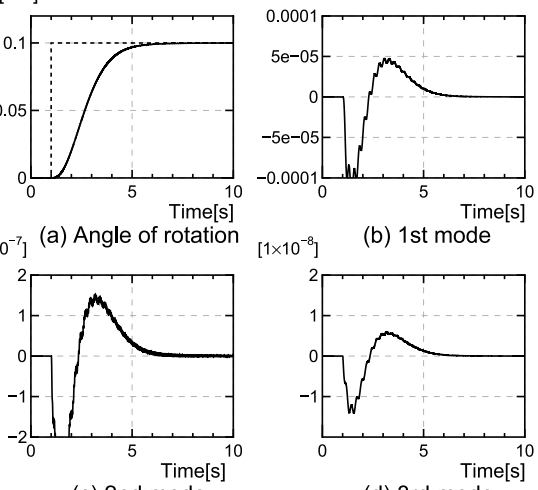

(b) 1 st mode

(c) 2nd mode

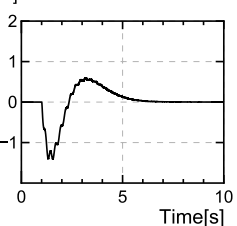

(d) 3rd mode

図 5 従来法によるシミュレーション結果 (応用例 1-Case1)

Fig. 5. Simulation results via conventinal method (Example1-Case1)
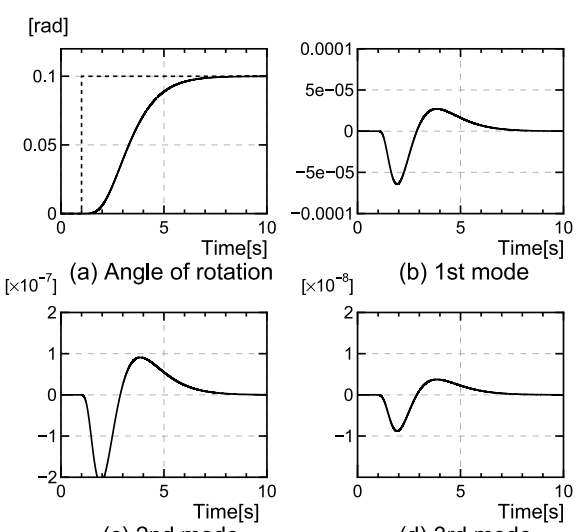

(c) 2nd mode

(d) 3rd mode

図 6 提案法によるシミュレーション結果

(応用例 1-Case2)

Fig. 6. Simulation results via proposed method (Example1-Case2)

$$
\begin{aligned}
& \left\{H_{m}(r)+m_{p} \Phi_{m}(L)\right\} \ddot{X}(t) \\
& \quad+\rho_{L} A_{L}\left\{\ddot{P}_{m}(t)+\Gamma_{m} \dot{P}_{m}(t)+\Lambda_{m} P_{m}(t)\right\} \\
& \quad+\left\{E_{m}(r)+m_{p}(l+L) \Phi_{m}(L)\right\} \ddot{\theta}(t) \\
& \quad-\left\{H_{m}(r)+m_{p} \Phi_{m}(L)\right\} g \theta(t)=O_{m \times 1}
\end{aligned}
$$

を得る。但し，

$m_{\theta}=m_{h} l_{c}+\rho_{L} A_{L} L\left(l+\frac{L}{2}\right)+m_{p}(l+L)$,

$J_{\theta}=J_{0}+m_{h} l_{c}^{2}+\rho_{L} A_{L} L\left(l^{2}+l L+\frac{L^{2}}{3}\right)+m_{p}(l+L)^{2}$,

$E_{m}(r)=\left[e_{1}(r), \cdots, e_{i}(r), \cdots, e_{m}(r)\right]^{T}, \cdots(38)$

$H_{m}(r)=\left[h_{1}(r), \cdots, h_{i}(r), \cdots, h_{m}(r)\right]^{T}, \cdots(39)$

$\Phi_{m}(L)=\left[\phi_{1}(L), \cdots, \phi_{i}(L), \cdots, \phi_{m}(L)\right]^{T}$,

$\Lambda_{m}=\operatorname{diag}\left[\lambda_{1}, \cdots, \lambda_{i}, \cdots, \lambda_{m}\right]$,

$\Gamma_{m}=2 \zeta_{L} \Lambda_{m}, P_{m}(t)=\left[p_{1}(t), \cdots, p_{i}(t), \cdots, p_{m}(t)\right]^{T}$

とする(詳細は付録 3 を参照のこと)。(35) 式は台車の並進 運動方程式，(36) 式は振子の回転方程式，(37) 式は $m$ 次 元の振子の振動方程式を表す。 $V^{r e f}(t)$ は速度指令型サー 


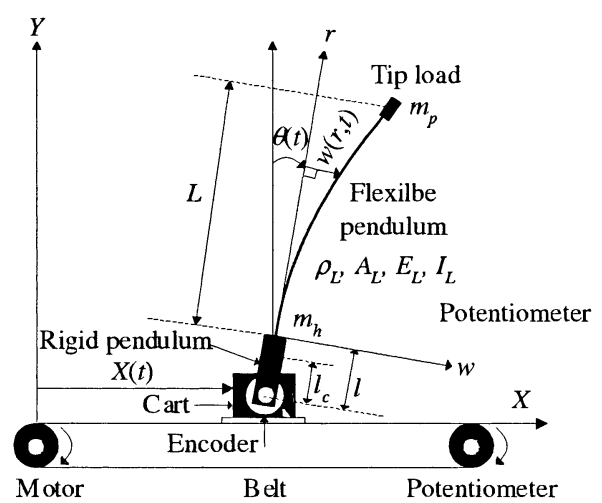

図 7 1 リンク・フレキシブル倒立振子-台車系

Fig. 7. 1 link flexible inverted pendulum and cart system

ボアンプの指令電圧, $\zeta_{c}, \xi_{c}$ は台車の減衰係数と電圧-加速 度変換係数 $, l, l_{c}$ は剛体振子の全長と回転軸から質量中心 までの長さ， $L$ は梁の全長， $\rho_{L}$ は梁の面密度， $A_{L}$ は梁の 断面積 (厚み $W_{L} \times$ 幅 $T_{L}$ )， $E_{L}$ は梁のヤング率， $I_{L}$ は梁 の断面 2 次モーメント, $m_{h}$ は剛体振子の質量, $w(r, t)$ は 梁上の任意の点における弾性変位とおく。また， $J_{0}$ はモ一 タのロータの慣性モーメント， $D_{\theta}$ はロータ回りの粘性摩 擦係数, $e_{i}(r)$ は回転と振動の慣性に関するカップリング係 数, $\phi_{i}(L)$ は先端での振動の固有関数, $p_{i}(t)$ は振動のモ一 ド変数, $\lambda_{i}$ は振動の固有値, $\zeta_{L}$ は振動の減衰係数, $g$ は重 力加速度である。

本論文では，振動モードを $m=2$ まで考え，(35) 式及 び (36) 式より剛体モードからなる $n=4$ の線形な状態空 間モデル

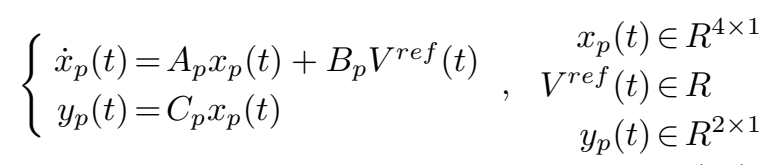

を設計モデルとして用いる ${ }^{(2)}$ 。但し，

$$
\begin{aligned}
& x_{p}(t)=\left[\begin{array}{llll}
X(t) & \theta(t) & \dot{X}(t) & \dot{\theta}(t)
\end{array}\right]^{T}, \\
& A_{p}=\left[\begin{array}{cc}
O_{2} & I_{2} \\
-M_{p}^{-1} K_{p} & -M_{p}^{-1} D_{p}
\end{array}\right], B_{p}=\left[\begin{array}{c}
O_{2 \times 1} \\
M_{p}^{-1} T_{p}
\end{array}\right], \\
& C_{p}=\left[\begin{array}{ll}
I_{2} & O_{2}
\end{array}\right] \text {, } \\
& M_{p}=\left[\begin{array}{cc}
1 & 0 \\
m_{\theta} & J_{\theta}
\end{array}\right], D_{p}=\left[\begin{array}{cc}
\zeta_{c} & 0 \\
0 & D_{\theta}
\end{array}\right], \\
& K_{p}=\left[\begin{array}{cc}
0 & 0 \\
0 & -m_{\theta} g
\end{array}\right], T_{p}=\left[\begin{array}{c}
\xi_{c} \\
0
\end{array}\right]
\end{aligned}
$$

とする。ここで, 設計の見通しをよくするため，(40) 式を 応用例 1 と同樣に (25) 式を用いて可制御正準系に変換す ると,

$$
\begin{cases}\dot{x}_{r}(t)=\bar{A}_{r} x_{r}(t)+\bar{B}_{r} V^{r e f}(t) & , \begin{array}{l}
x_{r}(t) \in R^{4 \times 1} \\
y_{r}(t)=\bar{C}_{r} x_{r}(t)
\end{array} \\
y_{r}(t) \in R^{2 \times 1}\end{cases}
$$

を得る。但し, $x_{r}(t), \bar{A}_{r}, \bar{B}_{r}, \bar{C}_{r}$ は応用例 1 の (28) 式
表 3 物理パラメータ

Table 3. Physical parameters

\begin{tabular}{c|c||c|c}
\hline \hline Parameter & Value & Parameter & Value \\
\hline \hline$L[\mathrm{~m}]$ & 0.29 & $A_{L}\left[\mathrm{~m}^{2}\right]$ & $6.49 \times 10^{-5}$ \\
\hline$W_{L}[\mathrm{~m}]$ & $2.20 \times 10^{-3}$ & $T_{L}[\mathrm{~m}]$ & $2.95 \times 10^{-2}$ \\
\hline$E_{L}\left[\mathrm{~N} / \mathrm{m}^{2}\right]$ & $7.05 \times 10^{10}$ & $I_{L}[\mathrm{~m}]$ & $2.62 \times 10^{-11}$ \\
\hline$\rho_{L}\left[\mathrm{~kg} / \mathrm{m}^{3}\right]$ & 2690 & $m_{p}[\mathrm{~kg}]$ & 0.02676 \\
\hline$J_{0}\left[\mathrm{kgm}^{2}\right]$ & $6.71 \times 10^{-5}$ & $D_{\theta}[1 / \mathrm{s}]$ & $2.00 \times 10^{-4}$ \\
\hline$l[\mathrm{~m}]$ & 0.052 & $l_{c}[\mathrm{~m}]$ & 0.02207 \\
\hline$g\left[\mathrm{~m} / \mathrm{s}^{2}\right]$ & 9.807 & $\zeta_{L}$ & $1.00 \times 10^{-5}$ \\
\hline$\zeta_{c}[1 / \mathrm{s}]$ & 240 & $\xi_{c}\left[\mathrm{~m} /\left(\mathrm{s}^{2} \mathrm{~V}\right)\right]$ & 90 \\
\hline$f_{1}[\mathrm{~Hz}]$ & 12.2 & $f_{2}[\mathrm{~Hz}]$ & 103.6 \\
\hline$m_{h}[\mathrm{~kg}]$ & $2.12 \times 10^{-2}$ & & \\
\hline \hline
\end{tabular}

表 4 設計パラメータ

Table 4. Design parameters

\begin{tabular}{c|c||c|c}
\hline \hline Parameter & Value & Parameter & Value \\
\hline \hline$f_{F}$ & 8.0 & $\lambda_{d 1}$ & 33.1 \\
$\zeta_{F}$ & 1.0 & $\lambda_{d 2}$ & 1.1 \\
$g_{F}$ & $(2 \pi 8.0)^{2}$ & $\lambda_{d 3}$ & 44.7 \\
\hline$a_{f}$ & 1.0 & $\lambda_{d 4}$ & 11.1 \\
$b_{f}$ & 2526.6 & $\lambda_{d 5}$ & 6.1 \\
$\bar{c}_{f}$ & -1.0 & $\lambda_{d 6}$ & 1.0 \\
$\bar{d}_{f}$ & -101.5 & & 96.2 \\
$\Lambda_{r 1}$ & $\operatorname{diag}[-2.0,-3.0,-5.0]$ & & -406.3 \\
$\Lambda_{r 2}$ & -243.9 & $J_{n}$ & 20.8 \\
$\Lambda_{s}$ & -5.0 & & 14.8 \\
\cline { 1 - 2 } $\mathrm{R}^{r e f}$ & 1.0 & & $1.4 \times 10^{-2}$ \\
$\mathrm{I}^{r e f}$ & 1.6 & & $5.6 \times 10^{-2}$ \\
\hline \hline
\end{tabular}

（30) 式と同樣である。このときの物理パラメータを表 3 に示す。

〈3. 2. 2〉 サーボ問題 (応用例 2) 具体的には次のサー ボ問題を考え，以下に示す 2 つのケースを比較する。 サーボ問題: $\quad t=1[\mathrm{~s}]$ で台車の位置 $X(t)$ を目標値 $0.1[\mathrm{~m}]$ のステップ信号に追従

Case1 従来法を用いて設計する。評価関数

$$
J_{q}=\int_{0}^{\infty}\left\{\dot{x}_{s v}(t)^{T} Q_{s v} \dot{x}_{s v}(t)+\left(\dot{V}^{r e f}(t)\right)^{2}\right\} d t,
$$

$Q_{s v}=\operatorname{diag}\left[\begin{array}{llllll}5 & 1 & 5 & 1 & 0 & 0\end{array}\right]$

を最小にする問題とし，少の安定化制御則から得られる 最適制御入力

$$
V^{r e f}(t)=-k_{r} \hat{x}_{p}(t)-k_{F} x_{F}(t)-k_{s} \int_{0}^{t} e(\tau) d \tau
$$

を用いる。但し， $k_{r} \in R^{1 \times 4}, k_{F} \in R^{1 \times 2}, k_{s} \in R$ とし， $\hat{x}_{p}(t)$ は同一次元オブザーバ(極 $\left.[-250,-8+3 \mathrm{i},-8-3 \mathrm{i},-5]\right)$ に よって推定する。また, 前置フィルタの遮断特性は, $1 \mathrm{st}$ 振動モード以上を抑制するため, $f_{F}=8.0[\mathrm{~Hz}], \zeta_{F}=1.0$ とする。

Case2 提案法を用いて設計する。設計パラメータを表 4 に示す。なお，同一次元オブザーバの極は Case1 と同 樣とし, 評価関数は応用例 1 の (33) 式を用いる。

图 8 及び図 9 に, 各々従来法及び提案法によるシミュレー ション結果を示す。各 Case の (a), (b), (c), 及び (d) は， 各々台車の位置, 振子の角度, 1st 振動モ一ド, 及び 2 nd 振 動モードの時間応答である。 

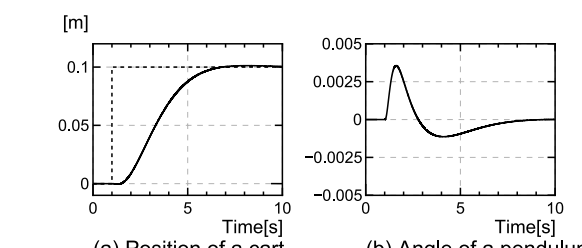

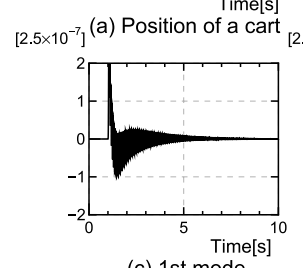

(c) 1st mode

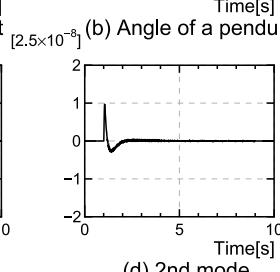

(d) 2nd mode
図 8 従来法によるシミュレーション結果

(応用例 2-Case1)

Fig. 8. Simulation results via conventinal method (Example2-Case1)
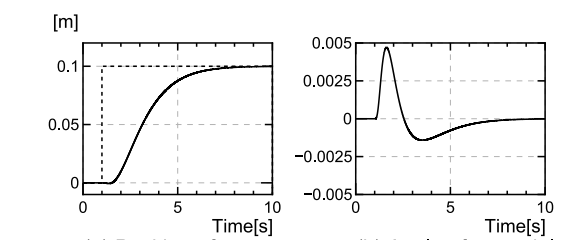

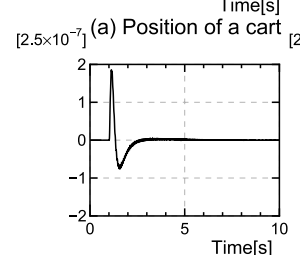

(c) 1 st mode

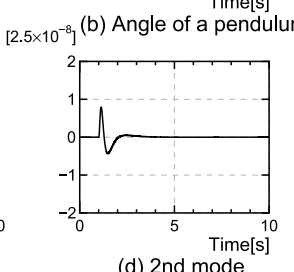

(d) 2nd mode
図 9 提案法によるシミュレーション結果

(応用例 2-Case2)

Fig. 9. Simulation results via proposed method (Example2-Case2)

Case1 では, 設計仕樣 S.1) 及びS.2) を実現しているが， 特に, 2 nd 振動モードの減衰性が悪い応答となっている。 のことは, 応用例 1 と同樣に, 状態フィードバックより得ら れたフィルタの遮断特性 $\left(f_{F}^{\prime}=12.24[\mathrm{~Hz}], \zeta_{F}^{\prime}=1.98\right)$ が 所望の前置フィルタの遮断特性 $\left(f_{F}=8.0[\mathrm{~Hz}], \zeta_{F}=1.0\right)$ より劣化する為, 弾性振動の減衰性が劣化しスピルオーバ 現象が生じた為である。

Case2 も同樣に設計仕樣 S.1) 及び S.2) を実現してい る。さらに, 過渡特性 (速応性及び減衰性) は Case1 と比 較して良好であり，応用例 1 と同樣に，評価関数による最 適化及び前置フィルタの効果か確認できる。以上の結果か ら，弾性を有する劣駆動系に対しても提案する制御系の有 効性が示された。

\section{4. おわりに}

本論文では, 従来の状態フィードバック制御では前置フィ ルタの遮断特性を任意に指定できない問題を解決する為 ,与 えられた設計仕樣を満足するようなデュアルオブザーバを 併合したサーボ系を提案した。提案法では, デュアルオブ ザーバと制御対象の直結系の入力空間の次数を高めること で, システム行列の構造までも考慮した極配置が可能となつ た。乥の結果，所望の高域遮断特性を有する前置フィルタ
が実現できた。数値シミュレーションでは,, 2 つの柔軟構 造物を応用例に挙げて, 従来法と提案法を比較して振動の 減衰性，過渡特性の観点から検証し，提案法の有効性を示 した。今後の課題としては，ロバスト制御に対する検討が 挙げられる。

(平成 18 年 3 月 22 日受付, 平成 18 年 8 月 28 日再受付)

$$
\text { 文献 }
$$

(1) Y. Sakawa, F. Matsuno, Y. Osawa, M. Kiyohara, and T. Abe: "Modeling and Vibration Control of a Flexible Manipulator with Three Axes by using Accelerometers", JRSJ, Vol.6, No.1, pp.42-51 (1987) (in Japanese)

坂和愛幸・松野文俊・大澤善樹・清原 誠・阿部敏久 : $\ulcorner 3$ 自由度フ レキシブル・マニピュレータのモデリングと加速度センサを用いた 振動制御」，JRSJ , 6, 1, pp.42-51 (1987)

( 2 ) Y. Morita, F. Matsuno, M. Ikeda, Y. Kobayashi, H. Ukai, and H. Kando: "PDS Control of a One-Link Flexible Arm with a Non-Symmetric Rigid Tip Body", Vol.16, No.1, pp.29-37 (2003) (in Japanese)

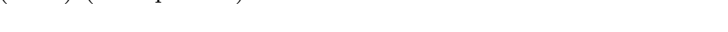
「非対称な岡体負荷を持つ 1 リンクフレキシブルアームの PDS 制 御」, システム制御情報学論誌, 16, 1, pp.29-37 (2003)

(3) K. Yamamoto, K. Takamura, T. Watanabe, and K. Seto: "Robust Vibration Control of Flexible Robot Arm Taking Account of and Uncertainty in Bending and Torsional Coupling", JSME(C), Vol.70, No.695, pp.1922-1928 (2004) (in Japanese)

山本幸典・高村耕平・渡辺 亨・背戶一登 :「不確かな曲げねじれ 連成振動を考慮したフレキシブルロボットアームの H $\mathrm{H}$ ロバスト 振動制御」, 日本機械学会論文集 (C 編)，70，695，pp.1922-1928 (2004)

(4) H. Nishimura, O. Onuki, K. Nonami, and T. Totani: "Design of $H^{\infty}$ Servo Compensator for A Cart and Inverted Flexible Pendulum System", SICE, Vol.32, No.7, pp.1035-1042 (1996) (in Japanese)

西村秀和・大貫 修・野波健蔵・戶谷隆美：「弾性倒立振子-台車 系に対する $H^{\infty}$ サーボ設計」, 計測自動制御学会論文集, 32, 7, pp.1035-1042 (1996)

( 5 ) T. Kida, M. Ikeda, and I. Yamaguchi: "Optimal Regulator with Low-Pass Property and Its Application to LSS Control", SICE, Vol.25, No.4, pp.448-454 (1989) (in Japanese) 木田隆・池田雅夫・山口 功 : 「高域遮断特性を持たせた最適レ ギュレータと产の大型宇宙構造物の制御への応用」, 計測自動制御 学会論文集, 25, 4,pp.448-454 (1989)

(6) Y. Morita, H. Ukai, H. Kando, and F. Matsuno: "Position Control of Flexible Inverted Pendulum Using FrequencyDependent Optimal Servo System", JSME(C), Vol.65, No.633, pp.1816-1822 (1999) (in Japanese) 森田良文・鵜飼裕之・神藤 久. 松野文俊 : 「周波数依存型最適サ一 ボ系によるフレキシブル倒立振子の位置決め制御」, 日本機械学会 論文集 (C 編)，65，633，pp.1816-1822 (1999)

（7）岩井善太·井上 昭·川路茂保:「オブザーバ」,コロナ社, pp.217-222 (1988)

( 8 ) K. Fuwa, T. Narikiyo, and Y. Funahashi: "Construction of a Control System for Disturbance Rejection Using a Dula Observer", EEIJ, Vol.138, No.4, pp.50-60 (2002)

(9) K. Fuwa, T. Narikiyo, and H. Kando: "Disturbance Rejection of Multiple-Input Systems Using a Dula Observer", SICE, Vol.39, No.2, pp.110-119 (2003) (in Japanese)

不破勝彦・成清辰生・神藤 久:「デュアルオブザーバを用いた多入 力系での外乱抑制」, 計測自動制御学会論文集, 39, 2, pp.110-119 (2003)

(10) K. Fuwa, T. Narikiyo, and H. Kando: "Zero Assignment Using a Dula Observer", EEIJ, Vol.154, No.3, pp.38-47 (2006)

(11) K. Fuwa, T. Narikiyo, and H. Kando: "A Study on Model Matching Problem using a Dula Observer", SICE, Vol.41, No.4, pp.322-329 (2005) (in Japanese)

不破勝彦・成清辰生・神藤 久:「デュアルオブザーバを用いたモ デルマッチング問題の一考察」, 計測自動制御学会論文集 , $\mathbf{4 1}, 4$, pp.322-329 (2005)

(12) H. Kanoh: "Distributed Parameter Models of Flexible Robot Arms", JRSJ, Vol.6, No.5, pp.430-435 (1988) (in Japanese) 
嘉納秀明: 「フレキシブルアームの分布定数系」, 日本ロボット学誌, 6, 5, pp.430-435 (1988)

（13）伊藤正美：「自動制御概論 (上)」，昭晃堂，pp.91-95 (1998)

\section{付 録}

1.

(16) 式は

$$
\begin{aligned}
\left|\begin{array}{ccc}
s-\Lambda_{r 2} & 0 & -1 \\
-\bar{C}_{s v N} & s-\Lambda_{s} & 0 \\
b_{f} J_{n 1 n} & b_{f} J_{n 2} & s-\rho_{1}
\end{array}\right| \\
=s^{3}-\left(\Lambda_{r 2}+\Lambda_{s}+\rho_{1}\right) s^{2} \\
\quad+\left(\Lambda_{r 2} \rho_{1}+b_{f} J_{n 1 n}+\Lambda_{s} \Lambda_{r 2}+\Lambda_{s} \rho_{1}\right) s \\
\quad-\Lambda_{s}\left(\Lambda_{r 2} \rho_{1}+b_{f} J_{n 1 n}\right)+\bar{C}_{s v N} b_{f} J_{n 2} \\
=0
\end{aligned}
$$

となる。このときの安定性の条件は

$$
\begin{aligned}
\Lambda_{r 2}+\Lambda_{s}+\rho_{1} & <0 \\
\Lambda_{r 2} \rho_{1}+\rho_{2}+\Lambda_{s} \Lambda_{r 2}+\Lambda_{s} \rho_{1} & >0 \\
\Lambda_{s}\left(\Lambda_{r 2} \rho_{1}+\rho_{2}\right)-\bar{C}_{s v N} b_{f} J_{n 2} & <0
\end{aligned}
$$

となる。このとき , $\left|s I_{N-1}-A_{D}\right|=\prod_{i=1}^{N-1}\left(s+\lambda_{d i}\right)$ の係 数比較より, $\rho_{2}$ は

$$
\begin{aligned}
& \rho_{2}:=b_{f} J_{n 1 n}=\sum_{i=1}^{N-2} \sum_{j=i+1}^{N-1} \lambda_{d i} \lambda_{d j}-\rho_{1} \operatorname{tr} \bar{A}_{r}-a_{r(n-1)}, \\
& b_{f} J_{n 2}=\frac{1}{\bar{C}_{\text {svn }}} \prod_{i=1}^{6} \lambda_{d i}
\end{aligned}
$$

となる。但し, $a_{r(n-1)}$ は $\bar{A}_{r}$ の特性多項式の $n-2$ 次の 項の係数である。すなわち，これらの条件を満足するよう にデュアルオブザーバの特性根 $-\operatorname{Re} \lambda_{d i}<0, \operatorname{Re} \Lambda_{r 2}<0$, 及び $\operatorname{Re} \Lambda_{s}<0$ を選ぶこととなる。

2.

(20) 式 $\sim(22)$ 式の第 $i$ 成分は, 以下のよう表される。

$$
\begin{aligned}
& e_{i}(r)=\rho_{L} A_{L} \int_{0}^{L} r \phi_{i}(r) d r, \\
& \phi_{i}(r)=-\frac{1}{C_{i}}\left[\left\{\cos \left(\frac{\beta_{i}}{L} r\right)-\cosh \left(\frac{\beta_{i}}{L} r\right)\right\}\right. \\
& \left.-\gamma_{i}\left\{\sin \left(\frac{\beta_{i}}{L} r\right)-\sinh \left(\frac{\beta_{i}}{L} r\right)\right\}\right] \text {, } \\
& \lambda_{i}=\frac{E_{L} I_{L}}{\rho_{L} A_{L}}\left(\frac{\beta_{i}}{L}\right)^{4} .
\end{aligned}
$$

但し,

$$
\begin{array}{r}
C_{i}=\left\{L+\frac{\rho_{L} A_{L}}{m_{p}}\left(\frac{L}{\beta_{i}}\right)^{2}\left(\frac{1+\cos \beta_{i} \cosh \beta_{i}}{\sin \beta_{i}+\sinh \beta_{i}}\right)^{2}\right\}^{\frac{1}{2}}, \\
\ldots \ldots \ldots \ldots \ldots \ldots \ldots \ldots \ldots \text { (付 } 3) \\
\left.\gamma_{i}=\frac{\cos \beta_{i}+\cosh \beta_{i}}{\sin \beta_{i}+\sinh \beta_{i}} \cdots \ldots \ldots \ldots \ldots \text { (付 } 4\right)
\end{array}
$$

とする。このとき, $\beta_{i}$ は次の非線形超越代数方程式

$$
0=1+\cosh \beta_{i} \cos \beta_{i}+\frac{m_{p}}{\rho_{L} A_{L}}\left(\frac{\beta_{i}}{L}\right) \times
$$$$
\left(\sinh \beta_{i} \cos \beta_{i}-\cosh \beta_{i} \sin \beta_{i}\right)
$$

の解である。

3.

(38) 式 $\sim(39)$ 式の第 $i$ 成分は, 以下のよう表される。

$$
\begin{aligned}
& e_{i}(r)=\rho_{L} A_{L} \int_{0}^{L}(l+r) \phi_{i}(r) d r, \\
& h_{i}(r)=\rho_{L} A_{L} \int_{0}^{L} \phi_{i}(r) d r .
\end{aligned}
$$

但し， $\phi_{i}(r), \lambda_{i}, C_{i}, \gamma_{i}$, 及び非線形超越代数方程式は, 付録 2 の (付 1$)$ 式 $\sim($ 付 5$)$ 式と同樣である。

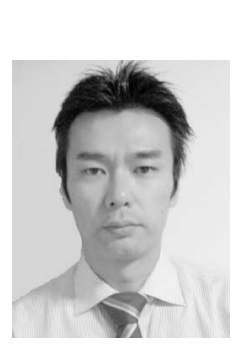

(正員) 2000 年名古屋工業大学大学院工学研究 科博士前期課程修了。同年岐阜工業高等専門学校 電子制御工学科助手。制御工学の研究に従事。修 $士$ (工学)。電気学会, 日本機械学会, 日本ロボッ 卜学会, 計測自動制御学会会員。

不 破 勝彦 (非会員) 2000 年名古屋工業大学大学院工学研

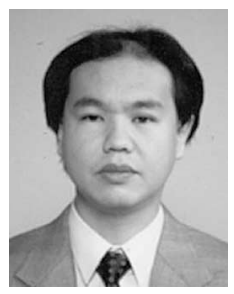
究科博士後期課程修了。同年名古屋工業大学電気 情報工学科助手。制御系設計法の開発に従事。

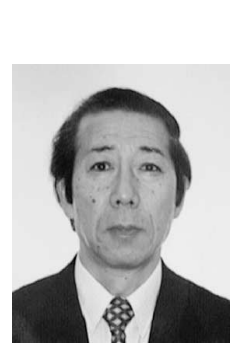

久 (正員) 1970 年京都大学大学院電気工学専攻修士 課程修了。1974 年名古屋工業大学共通講座教室助 手。1988 年同大学電気情報工学科助教授。1998 年同大学電気情報工学科教授。ディジタル制御, 多次元ディジタル信号処理, 電力制御, 大規模シ ステム理論などに関する研究に従事。工学博士。 計測自動制御学会, システム制御情報学会, IEEE 会員。

鈴 木 崇 史 (学生員) 2005 年名古屋工業大学電気情報工学

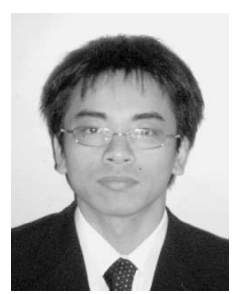
科卒業。同年名古屋工業大学大学院工学研究科博 士前期課程に進学, 現在に至る。制御工学の研究 に従事。 